\title{
The Blue-cheeked Amazon Amazona dufresniana: a review
}

\author{
D. C. WEGE and N. J. COLLAR
}

\section{Summary}

The Blue-cheeked Amazon Amazona dufresniana occupies tropical and subtropical forest in north-eastern South America in eastern Venezuela, Guyana, Surinam and French Guiana, where it remains a very little known species, apparently living in scattered pairs in the interior when breeding, but with irregular movements to the coastal regions in (albeit now small) flocks in July and August. Nothing is recorded of its feeding or breeding habits, nor is it known to be at serious risk from habitat loss or trade, although both these factors may have operated against the species in the past. It occurs in two protected areas and deserves to be a target species of any fieldwork in the region aimed at obtaining status information on areas or faunas.

\section{Introduction}

The Blue-cheeked Amazon Amazona dufresniana is one of the most enigmatic of South American parrots. Variously regarded as conspecific with the Red-browed Amazon A. rhodocorytha of eastern Brazil and with both that and the Red-tailed Amazon A. brasiliensis of south-east Brazil (see, e.g., Forshaw 1978, Meyer de Schauensee 1970, Meyer de Schauensee and Phelps 1978), it has in recent years become more usual to accept independent specific status for all three forms (Ridgely 1981, Forshaw 1989; also Berlioz 1962).

Although the Blue-cheeked Amazon's range is relatively restricted, it spans the three Guianas and penetrates south and eastern Venezuela, and might therefore be expected to have generated sufficient data through various avifaunal studies in these countries for the basic facts of its status, distribution and ecological needs to have been assembled. At the time of the global review of species issued in Birds to watch (Collar and Andrew 1988) the species was not considered at risk nor even a borderline case. However, the IUCN categories (which ICBP has always followed in its threatened species analyses) allow for an "Insufficiently Known" listing of a taxon if the suspicion of threatened status is merited. During 1988 the results of work on Venezuelan parrots by Desenne and Strahl (1991) came into circulation and, because of their concern for the species in Venezuela, ICBP took the precautionary view of treating it overall as at risk and so included it in various reviews commissioned for particular meetings (e.g. Collar and Juniper in press); the species would then have had the category "Insufficiently Known".

Thus it was that when we began accumulating material on the rarer and less known parrots in preparatory analysis for ICBP's forthcoming Threatened birds of 
the Americas, the Blue-cheeked Amazon was one of the targets for detailed evaluation. Having undertaken this evaluation, however, we are forced to conclude that it is unlikely that the species is currently threatened; we offer the evidence here as a matter of public information and in the hope that it will stimulate further study and indeed perhaps the disclosure of data of whose existence we have been unaware. In the following account, coordinates are derived from Paynter (1982) for Veriezuela and Stephens and Traylor (1985) for the Guianas, and we use the initials AMNH for American Museum of Natural History (New York), BMNH for British Museum of Natural History (Tring), CM for Carnegie Museum of Natural History (Pittsburgh), COP for Collección Ornitológica Phelps (Caracas), FMNH for Field Museum of Natural History (Chicago), MNHN for Museum National d'Histoire Naturelle (Paris), RMNH for Rijksmuseum van Natuurlijke Historie (Leiden), USNM for United States National Museum (Washington), WTMU for Wildlife Trade Monitoring Unit (Cambridge, U.K.) and ZMA for Zoologisch Museum (Amsterdam). Superscript numbers next to localities refer to the points marked on Figure 1.

\section{Distribution}

The Blue-cheeked Amazon is endemic to northern South America, being recorded from a small number of localities in south and eastern Venezuela, northern Guyana, north-eastern Surinam and north-eastern French Guiana. A recent review (Robiller 1990) maps the species throughout Amapa and the Amazon basin in Pará, Brazil, and states that it is known from north-eastern Pará; however, there appears to be no evidence for this. Recent records come from just a few localities in Guyana, Brownsberg Nature Park in Surinam, Nouragues Field Station in French Guiana and La Escalera in Venezuela.

Venezuela Most surprisingly, given the generalization of range in Meyer de Schauensee and Phelps (1978), the species appears to be known from just three specimens (in COP), two collected in eastern Bolivar state (on the Gran Sabana tablelands), one (a female) at Mission Kanavayen ${ }^{1}\left(5^{\circ} 38^{\prime} \mathrm{N} 61^{\circ} 48^{\prime} \mathrm{W}\right)$ near Ptaritepuí, at 1,000 $\mathrm{m}$ in September 1944, the other (also female) at Sororopán-tepuí $\left(5^{\circ} 45^{\prime} \mathrm{N} 61^{\circ} 43^{\prime} \mathrm{W}\right)$ at $1,700 \mathrm{~m}$ in August 1944, with a third (a male) in Amazonas state at "Alto Ocamo" ${ }^{\prime \prime}\left(c .2^{\circ} 48^{\prime} \mathrm{N} 65^{\circ} 14^{\prime} \mathrm{W}\right)$ on the upper Río Ocamo, at $1,200 \mathrm{~m}$ in April 1972 (this last record, representing a remarkable range extension, not having been reported in recent literature, e.g. Meyer de Schauensee and Phelps 1978). Apart from these specimens, there have been a number of sightings from La Escalera on the Gran Sabana, which are as follows: two at $\mathrm{km} 102^{4}$ between December and February 1982/1983 (Fairbank and Gantlett 1983); between km 128 and 135 in 1982 (Gardner 1982); four on 2 January 1989 at $\mathrm{km} 139^{5}$ (N. J. Gardner and D. Brisley in litt. 1989); and $132 \mathrm{~km}$ south of El Dorado ${ }^{6}$ on La Escalera near the treeline (D. Willis in litt. 1991).

Despite or perhaps because of the general paucity of information, Ridgely (1981) suspected that the species is basically a "pantepuí endemic, occurring primarily in the tepuí region of southern Venezuela and adjacent west Guyana, moving seasonally or erratically to the coastal plain of the Guianas". The 


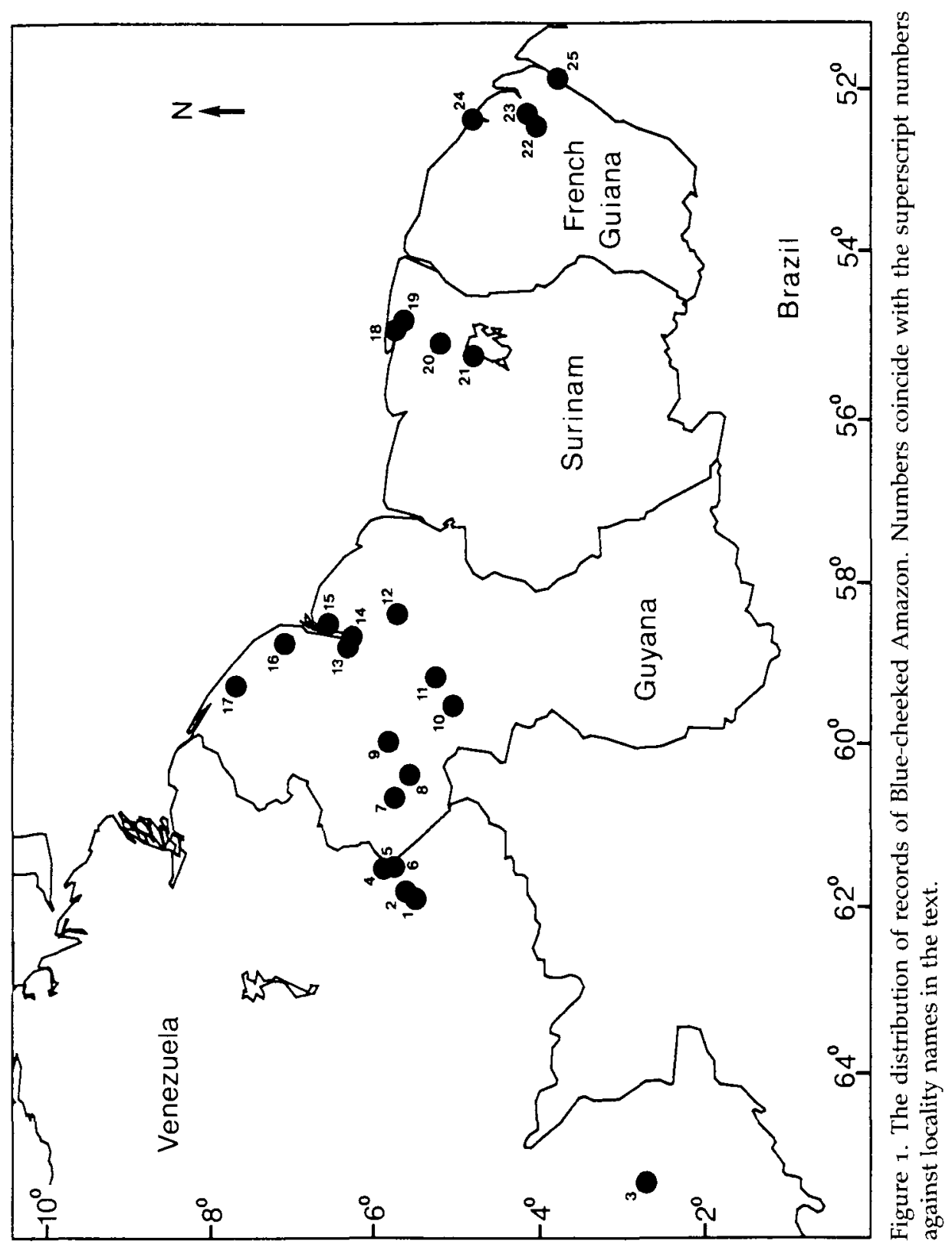


Venezuelan specimens certainly represent the highest altitudinal and the westernmost records for the species.

Guyana Records of the species come from a number of localities, all north of $5^{\circ} \mathrm{N}$. Inland, the species has been recorded from the River Kamarang ${ }^{7}\left(c .5^{\circ} 53^{\prime} \mathrm{N}\right.$ $60^{\circ} 35^{\prime} \mathrm{W}$ ) where at $460 \mathrm{~m} \mathrm{H}$. Whitely collected birds in May, November (four specimens) and December 1885, and November 1886 (in AMNH, BMNH, MNHN, ZMA); these appear to be the only records from this far west in Guyana, although E. P. McLoughlin saw two pairs of what was almost certainly this species at $560 \mathrm{~m}$ in August 1967 at Imbaimadai ${ }^{8}\left(c .5^{\circ} 42^{\prime} \mathrm{N} 60^{\circ} 18^{\prime} \mathrm{W}\right)$ on the upper Mazaruni River (Forshaw 1978, 1989). East from here the species is recorded from: Kamakusa ${ }^{9}\left(5^{\circ} 57^{\prime} \mathrm{N} 59^{\circ} 54^{\prime} \mathrm{W}\right.$; at $\left.100 \mathrm{~m}\right)$ on the south bank of the Mazaruni River (Salvin 1886); Kaietur Falls $\mathrm{s}^{10}\left(5^{\circ} 10^{\prime} \mathrm{N} 59^{\circ} 28^{\prime} \mathrm{W}\right.$; at $\left.366 \mathrm{~m}\right)$, where two birds (in FMNH) were taken on 5 March 1912; and from $45 \mathrm{~km}$ further downstream (the Potaro River) at Potaro Landing ${ }^{11}\left(5^{\circ} 23^{\prime} \mathrm{N} 59^{\circ} 08^{\prime} \mathrm{W}\right.$; at $\left.100 \mathrm{~m}\right)$, where a female (in AMNH) was collected during August 1912 (also Snyder 1966). Two males were collected somewhere along the Demerara River in April 1874 and May 1908 (in BMNH and FMNH), and two pairs were seen at Wainibisi ${ }^{12}\left(5^{\circ} 51^{\prime} \mathrm{N} 58^{\circ} 21^{\prime} \mathrm{W}\right)$, a west bank affluent of the Demerara River, in May 1887 (Stephens and Traylor 1985, Schouten 1988).

Records on the coastal plain and related riverine localities (this paragraph) include Kartabu Point ${ }^{13}\left(6^{\circ} 23^{\prime} \mathrm{N} 58^{\circ} 41^{\prime} \mathrm{W}\right.$; at $\left.c .100 \mathrm{~m}\right)$, at the junction of the Cuyuni and Mazaruni Rivers, where W. Beebe collected birds (in AMNH: including a juvenile) in September 1920 and 1922 and on 13 March 1924 (a breeding male) and on 19 April 1924 (specimens in AMNH); Bartica ${ }^{14}\left(6^{\circ} 24^{\prime} \mathrm{N}\right.$ $58^{\circ} 21^{\prime} \mathrm{W}$; at $3 \mathrm{~m}$ ), at the junction of the Essequibo and Mazaruni Rivers, where $\mathrm{H}$. Whitely collected four on 10 October 1880 (skins in BMNH and MNHN) and Frank collected two on 12 October 1880 (in RMNH); J. J. Quelch collected a female here on 22 December 1897 (in USNM), with three more taken in 1911 and 1912 (in BMNH). In the winter of $1875 / 1876$ the species was recorded from a point along the Essequibo River, where a living example was taken for the Zoological Society Gardens in London (Lawrence 1880). Four specimens (in $\mathrm{BMNH}$ ) were taken in 1912 at Warimia $\mathrm{Creek}^{15}\left(c .6^{\circ} 42^{\prime} \mathrm{N} 58^{\circ} 28^{\prime} \mathrm{W}\right)$, an affluent of the Bonasika River $\left(6^{\circ} 45^{\prime} \mathrm{N} 58^{\circ} 30^{\prime} \mathrm{W}\right)$. Chubb (1916) recorded the species from the lower Essequibo River, into which the Bonasika River flows. Schomburgk (18471848) observed a large number on the Sururu $\operatorname{River}^{16}$ (near its confluence with the Pomeroon River), on the coast (probably at $7^{\circ} 13^{\prime} \mathrm{N} 58^{\circ} 42^{\prime} \mathrm{W}$; map in Schomburgk 1847-1848, also Stephens and Traylor 1985). On 4 October $1988 \mathrm{~K}$. Schouten (in litt. 1988) saw a pair and heard some flying over at Kmabanna ${ }^{17}$ (untraced, but from the description at $c .7^{\circ} 50^{\prime} \mathrm{N} 59^{\circ} 13^{\prime} \mathrm{W}$ ).

Surinam There is relatively little precise distributional information for this species, although it is well known by the inhabitants of the interior who regularly report small flocks in their region (M. M. Held in litt. 1991). Haverschmidt (1955) collected it on the Maroni River, obviously some way upstream as it led him to state that the bird inhabits forests of the interior, a conclusion that was further enhanced by the collection of a male (in RMNH) on 1 July 1962 at Phedra ${ }^{20}$ $\left(5^{\circ} 20^{\prime} \mathrm{N} 55^{\circ} \mathrm{O}^{\prime} \mathrm{W}\right.$; at $50 \mathrm{~m}$, on the west bank of the Suriname Rivier). Sub- 
sequently, he collected the species in a more coastal region: a female on $17 \mathrm{July}$ 1962 on the Commewijne Rivier ${ }^{18}$ (probably at the mouth of Boven Cottica Rivier: Stephens and Traylor 1985); with a male on 17 August 1962 and two females 18 July 1963 (in RMNH) at Moripocreek or Moricocreek ${ }^{19}$ (= Commewijne Rivier, c.6o km north-east of Phedra, $5^{\circ} 46^{\prime} \mathrm{N} 54^{\circ} 46^{\prime} \mathrm{W}$ ) (specimens in RMNH). Haverschmidt (1968) also records the species as arriving in flocks during July/August in the forests of the coastal sand-ridge area, but no localities, numbers or dates are given (although he is possibly referring to the specimens collected in July/August 1962 and 1963). The only other locality known for Surinam is Brownsberg Nature Park ${ }^{21}\left(C .4^{\circ} 55^{\prime} \mathrm{N} 55^{\circ} 12^{\prime} \mathrm{W}\right.$ ) (Schulz et al. 1975) and, while again no details were given, P. W. Trail (in litt. 1991) has indicated that in recent years records within this protected area have been from the shores of Brokopondo Reservoir, although he himself did not see any in six months of fieldwork spread over December 1983 to March 1986.

French Guiana Records generally stem from the centre and east of the country, with specimens representing just three localities, only one of them during the last 70 years, as follows: an adult male (in AMNH) collected 8 January 1903 at Ipoucin Crique ${ }^{22}$ ( $27 \mathrm{~m}$; an east bank affluent of Fleuve Approuage at $c .04^{\circ} 09^{\prime} \mathrm{N}$ $52^{\circ} 24^{\prime} \mathrm{W}$ ) (von Berlepsch 1908; Stephens and Traylor 1985); a female 1 January and two males, 26 March 1918 (all in CM) at Pied Saut ${ }^{25}$ on the Fleuve Oyapock (unlocated but apparently above St Georges at the foot of rapids $c .03^{\circ} 53^{\prime} \mathrm{N}$ $51^{\circ} 48^{\prime} \mathrm{W}$, i.e. on the border with the Brazilian state of Amapá); a male taken 27 July and an adult on 28 July 1961 near Cayenne ${ }^{24}$ (in MNHN). Cayenne is also the type locality for Amazona dufresniana (Peters 1937). J.-M. Thiollay (in litt. 1991) notes that the species has been identified in the Nouragues Field Station ${ }^{23}$ in the north-east of the country, close to and just north-west of Ipoucin Crique, but is probably widely though sparsely distributed in the forested interior.

\section{Population}

With so few records from such a large area, subjective generalizations are unavoidable. Since it is uncertain what the population used to be and indeed what it stands at today, it is completely unclear whether the Blue-cheeked Amazon is declining in any significant manner. Several factors point to a possible decline: the flocks reported from the coast by Schomburgk in the 1840 (see below) and those mentioned by Haverschmidt (1968) have not been recorded since. Many observers, in Surinam especially, have failed to see the species despite considerable lengths of time in the field (see below).

Venezuela The statement in Meyer de Schauensee and Phelps (1978) that the species occurs in small flocks presumably rests on the reports of those who collected the three skins from which the species is known in the country (see Distribution). The sight records from La Escalera during the 1980s suggest the presence of at least a small number of birds in the area, although D. Willis (in litt. 1991) saw it only once there in three visits; while in a five-week survey on the Gran Sabana Desenne and Strahl (1991) saw no wild birds, merely three captive individuals. The general paucity of records, despite the accessibility and 
popularity of this part of Venezuela (with birdwatchers at least), suggests the presence of a very small or at least a very low density population in the region.

Guyana Snyder (1966) considered the species uncommon though fairly widespread in interior forests. Trappers, when asked about the species, regarded it as locally common in the Mazaruni area (Schouten 1988), which could explain the relatively high numbers collected at Bartica in the late nineteenth century. The same trappers mentioned that the birds are not very sociable, which to some extent explains the low incidence of records from the forested interior. The species appears to be more numerous in July and August in the coastal region. Schomburgk (1847-1848) encountered the species only once in the wild during his four-year journeying through Guyana, observing "a number of parrots" which he elsewhere called an "innumerable flock" near the confluence of the Sururu River with the Pomeroon (Chubb [1916] accidentally interpreted this as two records from the two rivers); he otherwise found only single captive birds in native villages, and generally pronounced the species uncommon. C. A. Lloyd (in Chubb 1916) likewise reported that it "is not a rare species, but is not very common". With 437 individuals exported from Guyana in 1978 (Niles 1981), and approximately 550 in the 1980 o (Schouten 1988) (see Threats), relatively large populations must exist (or have existed) in some areas of Guyana, although R. Low (in Ridgely 1982) suspected that some misidentification was involved in the rather high 1978 figure, a consideration that may equally apply to that for the 1980s. D. A. Wiedenfeld (in litt. 1991) considers that the species appears to be rare throughout Guyana, in the sense that birds cannot be located on any given day at a known site, and that it was apparently never very common.

Surinam Haverschmidt (1968) stated that the species is less common than the "rather common" Mealy Amazon Amazona farinosa, and occurs in small flocks. This was taken by Forshaw $(1978,1989)$ to mean that it is "fairly common". J. Ingels (in Ridgely 1981) considered it now rather rare in Surinam, recent observers failing to see it except as pets in Paramaribo (see Threats). P. W. Trail (in litt. 1991) in 24 months of field time in Surinam prior to 1986 never saw the species, a similar story being told by P. K. Donahue (in litt. 1991), who had no records in four months over the period 1979-1982, and Davis (1980) who, in calling the species rare, admits no records of it in over 12 visits to the country (Ridgely 1982). Recent reports from Brownsberg Nature Park (see Distribution) give no indication of the numbers involved, the evidence suggesting that they are at least seasonal at this site, and possibly irregular. Despite all the evidence to the contrary, the species is apparently still regularly seen in small flocks by the inhabitants of the interior (M. M. Held in litt. 1991) and may breed in the Tafelberg or Kayserberg of the centre and south of the country, but since 1986 it has been impossible to conduct fieldwork in the interior (including Brownsberg Nature Park) owing to continuing political disturbances.

French Guiana The only information apart from numbers associated with the distributional records is from J.-L. Dujardin (in litt. 1991), who has reports from local people that the species is generally uncommon, although abundance appears to vary so that in some years it is fairly common. Its apparent relative 
rarity is indicated by the fact that at the Saint Georges de l'Oyapock market in the period between I July and 1o August 1991 Dujardin counted 662 Orangewinged Amazona amazonica, 70 Mealy A. farinosa, but only seven Blue-cheeked Amazons.

\section{Ecological data}

The ecological requirements of the Blue-cheeked Amazon, including resultant displacements and usual breeding regime, remain very poorly known. It is known to fly higher above the canopy than other species of parrot and to keep strictly to the tops of trees (Haverschmidt 1968, M. M. Held in litt. 1991), factors which may well be responsible for the dearth of information on various elementary points in its biology. There are apparently no published records relating to its preferred food or breeding season, and nothing that relates to the nest or eggs (Chubb 1916, Haverschmidt 1955, Forshaw 1978). Even the matter of its social pattern is moot: trappers interviewed by Schouten (1988) thought it not very sociable, not mixing with other parrots, although seasonally it shows intraspecific gregariousness (see Population above). It is generally agreed that the species is probably widely distributed at low densities, in pairs or small flocks (possibly comprising two or three pairs) in the interior forests (Snyder 1966, J.-M. Thiollay in litt. 1991); larger flocks seem only to occur when populations shift towards the coast (see below).

In Venezuela the species has been recorded from rain- and cloud-forest areas of the lower subtropical zone, where it is said to occur in small flocks (Meyer de Schauensee and Phelps 1978), a judgement consistent with the subsequent sightings of between two and four birds in the same region (see Distribution and Population). At 1,000-1,700 $\mathrm{m}$, the Venezuelan records represent the highest altitudes known, all those in the Guianas coming from below $550 \mathrm{~m}$. Indeed, many records, especially in Guyana but also from Surinam and French Guiana, come from riverine gallery forest. This may genuinely be one of the species's preferred habitats but may also merely reflect the reliance on river transport by collectors and naturalists.

At any rate, the Guianas evidence contradicts some of the generalizations made about the species, such as Ridgely's (1982) statement that it is "found mostly in highlands between 500 and 1,500 m", and McLoughlin's (1970) that it "seems to be restricted mainly to the cooler, elevated forests of the interior" [of Guyana]. There seems to be little evidence for the suggestion (Ridgely 1981, 1982) that the species has been recorded from "more open areas and near natural savannas", unless this relates to the coastal forests, or indeed for the view (Ridgely 1981) that the bird is "basically a pantepui endemic, found primarily in the tepuí region of southern Venezuela and adjacent Guyana, moving seasonally (perhaps only erratically) to the coastal plain of the Guianas". In fact, as it appears that the species has been found in the interior forests of Guyana at least from August to May and French Guiana from January to March, the tepuí population could be argued instead to be a high altitude outpost of an otherwise lowland species. The breeding male at Kartabu in March, the juvenile at the same locality in September, and records from nearby Bartica from October to December suggest residence there throughout the year, although this locality 
lies athwart the putative boundary between "coastal plain" and "interior forests"'.

Nevertheless, it is clear that movements of some sort occur, not necessarily involving all the populations of a given region. During the period from at least August until May, the species appears to be sparsely distributed in tropical-zone forests $(15-550 \mathrm{~m}$ ) away from the coastal strip, but also in the more elevated subtropical forest $(1,100-1,700 \mathrm{~m}$ ) of Bolivar (Gran Sabana) and Amazonas, Venezuela, being recorded near the treeline on La Escalera at this time (D. Willis in litt. 1991). Towards the end of the long rainy season (July/August), however, small to large flocks have been observed along Surinam's coastal strip in the sand-ridge forests (Haverschmidt 1968), this appearing to be an occasional or irregular phenomenon (P. K. Donahue in litt. 1990). Haverschmidt (1968) mentions three other parrot species that move to the coastal region at the same time of year: Mealy Amazon, Dusky Parrot Pionus fuscus and Blue-headed Parrot $P$. menstruus. The Blue-headed Parrot is said to arrive in flocks, mostly in July, feeding in treetops mostly on seeds of the possum tree Hura crepitans. Schomburgk (1847-1848) recorded the large number at Sururu (near the coast of Guyana) as settling in mimosa and other berry-bearing trees, so the Bluecheeked Amazon and other parrot species may make these movements in response to the seasonal superabundance of food in the coastal region. This movement may also occur in French Guiana between June and August as reported by J.-L. Dujardin (in litt. 1991), and as indicated by specimens taken in July at "Cayenne" (see Distribution), although large flocks have not been recorded and the temporal abundance of food here is unknown; Dujardin notes that the numbers of birds vary between years.

Low (1972) mentions that E. P. McLoughlin in Guyana cared for a Bluecheeked Amazon for a month, saying that it appeared to suffer more than other species from the coastal heat. If this is true and the species prefers cooler temperatures, it could explain the relatively short period spent in coastal areas, the mean highest temperatures in coastal Surinam being from September to November, soon after the start of the long dry season (Haverschmidt 1968).

\section{Threats to the species}

The two most usual threats to Neotropical parrots, habitat loss and trade (Collar and Juniper in press), are not strikingly obvious in the case of the Blue-cheeked Amazon, which generally appears to be a naturally low-density species occupying a relatively restricted range. Ridgely (1981), in stating that the habitat in the species's range is virtually undisturbed, concluded that the "evident rarity cannot be ascribed to man's activities". Clearly, however, such a species is likely to be particularly vulnerable to perturbations in numbers or habitat brought about by forest clearance or direct human exploitation, and it is possible that some combination of the two may now apply, though clearly not strongly. It is worth remarking that a recent review did not consider the species as even locally (that is to say, at the equivalent of the national level) at risk in French Guiana (Thiollay 1988).

Habitat loss Unless the Blue-cheeked Amazon has some particular adaptation or 
dependence, which seems improbable (the closely related Red-browed or Redtailed Amazons do not: Collar and Gonzaga in prep.), habitat destruction, in the Guianas especially, cannot yet be judged a serious threat, as most of the habitat within the species's range remains virtually untouched (Ridgely 1981, Thiollay 1989, Mittermeier et al. 1990, D. A. Wiedenfeld in litt. 1991). However, Desenne and Strahl (1991) regard habitat destruction in Venezuela as a high threat to the species, presumably referring to the deforestation on the Gran Sabana. It may also be possible that the primarily coastal distribution of the human population in the Guianas (which holds 90-95\%: Mittermeier and van Roosmalen 1982, Sullivan 1990), and the inevitable habitat modification that has resulted (from expansion of agricultural lands and infrastructure), may account for the lack of recent sightings of seasonal flocks in this coastal strip.

Trade Historically the species appears to have been traded in minor volume. Tavistock (1929) reported that it was "not infrequently imported and does well in confinement" but went on to remark that it "seldom excels as a talker". By around 1970 it was almost unknown in captivity, with just six birds known to be held in Europe, and one being imported into the U.K. in 1971 (Low 1972). Since then the situation has altered, and trade may have become a significant problem at least in the western part of the species's range.

In Venezuela the legal trade in the Blue-cheeked Amazon was non-existent during the 1980s, with just one bird exported in 1985 (data from WTMU, Cambridge). Locally, Desenne and Strahl (1991) saw three in captivity during their survey of the Gran Sabana in Venezuela, suggesting at least an opportunistic local trade in this country.

In Guyana, the only country where the Blue-cheeked Amazon has been described as (at least locally) fairly common, the legal exportation of this species involved totals of 437 in 1978 and 543 during the period 1982-1989 (data from WTMU, Cambridge). In 1989, the government reduced the legal export quota for this species to zero, and as this is not one of the more colourful and popular parrots there is probably less pressure to trade it illegally than for some others (D. A. Wiedenfeld in litt. 1991).

In Surinam 28 birds were legally exported between 1982 and 1989 (data from WTMU, Cambridge). An export quota of 50 birds per year was introduced by the government in 1987 but since then, owing either to the species's rarity in the country or to the difficulty of catching it, traders have not yet managed to export more than 15 birds per year (M. M. Held in litt. 1991). A relatively recent observer (Ridgely 1981) has seen the species kept as pets in the capital Paramaribo, although it is apparently not often so kept in the villages of the interior (M. M. Held in litt. 1991).

In French Guiana the species was observed in one market in very small numbers in July and August 1991 (see Population), and has also been seen killed in July (no year given) (J.-L. Dujardin in litt. 1991), presumably being sold for food. This evidence from one part of the border region with Brazil suggests that trade in this species as pets and food could be widespread, albeit in low volume and only seasonal, throughout the territory. 


\section{Conservation}

The Blue-cheeked Amazon poses a common problem when setting priorities in species conservation. On the available evidence it appears to be an uncommon bird, always a source of concern if the distribution is limited, as here. Nevertheless, the extent of its habitat and the low levels of trade that it has endured suggest that it is not to be considered at risk for the moment. Against this must be set the legitimate preoccupation to be more fully informed, in case some unconsidered factor is in play. The costs of obtaining that information, especially when the hoped-for outcome is the reassurance that no more needs to be done, then have to be measured against the costs of projects known to be far more urgent and necessary. The very existence of this paper, published separately from and in advance of Threatened birds of the Americas, runs the risk of attracting undue attention (and hence money) to a species that might better be given to others whose plights and their remedies will only be widely understood when the book is published.

We therefore advocate a cautious approach to the conservation of the Bluecheeked Amazon. While it is clearly desirable that a study should illuminate the population densities, habitat, feeding and breeding requirements and migration of the species, the money to achieve this should ideally derive from academic resources or even from regional development funds, not from the conservation community (although endorsement by that community would be merited). Meanwhile, conservation bodies, both national and international, should integrate a concern to learn more of the Blue-cheeked Amazon into wider initiatives for eastern Venezuela and the Guianas, so that no opportunity is lost to obtain data on its distribution and biology during other surveys, whether of particular areas or of particular species. Among the more interesting points to resolve concerning distribution, worth mentioning here, is whether the Bluecheeked Amazon enters Brazil across the river frontier with French Guiana; Amapá remains a relatively little worked state (a seemingly strong population of Hyacinth Macaws Anodorhynchus hyacinthinus was found there in the $1890 \mathrm{~s}$ which never seems to have been looked for since: Collar and Gonzaga in prep.), and might yet contribute a minor range extension for the species.

It should be noted that, to date, the Blue-cheeked Amazon has been recorded from just two protected areas, Roraima National Park in Venezuela and Brownsberg Nature Park in Surinam, although it probably occurs at least seasonally in a number of coastal reserves in the latter.

\section{Acknowledgements}

Our thanks are due to the following people who so kindly responded to our requests for specimen label information: M. LeCroy (AMNH), J. Loughlin (CM), R. Aveledo (COP), D. E. Willard (FMNH), G. F. Mees (RMNH), J. Wattel and T. G. Prins (ZMA). We also extend our gratitude to P. K. Donahue, J.-L. Dujardin, M. M. Held, H. Reichart, J.-M. Thiollay, P. W. Trail, D. A. Wiedenfeld and D. Willis who all made valuable comments and contributed useful (and largely unpublished) information. Trade statistics were generously supplied by T. P. Inskipp at the Wildlife Trade Monitoring Unit (World Conservation Monitoring Centre, Cambridge, U.K.). 


\section{References}

von Berlepsch, H. (1908) On the birds of Cayenne. Novit. Zool, 15: 103-324.

Berlioz, J. (1962) Etude d'une collection d'oiseaux de Guyane française. Bull. Mus. Natn. Hist. Nat. (2)34: 131-143.

Chubb, C. (1916) Birds of British Guiana, 1. London: Bernard Quaritch.

Collar, N. J. and Andrew, P. (1988) Birds to watch: the ICBP world checklist of threatened birds. Cambridge: International Council for Bird Preservation (Techn. Publ. 8).

Collar, N. J. and Gonzaga, L. P. (in prep.) Draft texts of threatened Brazilian parrots for Threatened birds of the Americas.

Collar, N. J. and Juniper, A. T. (in press) Dimensions and causes of the parrot conservation crisis. In S. Beissinger and N. Snyder, New World parrots in crisis: solutions from conservation biology.

Davis, T. (1980) An annotated checklist of the birds of Suriname. Los Angeles: Los Angeles Audubon Society.

Desenne, P. and Strahl, S. D. (1991) Trade and the conservation status of the family Psittacidae in Venezuela. Bird Conserv. Internatn. 1: 153-169.

Fairbank, R. J. and Gantlett, S. J. M. (1983) Birds seen in Venezuela 24 Dec. 1982-21 Feb. 1983. Unpublished report.

Forshaw, J. M. (1978) Parrots of the world. Second (revised) edition. Melbourne: Lansdowne Editions.

Forshaw, J. M. (1989) Parrots of the world. Third (revised) edition. London: Blandford Press.

Gardner, N. J. (1982) A birder's guide to travel in Venezuela. Unpublished report.

Gardner, N. J. and Brisley, D. S. (1989) Birding trip to Venezuela. Unpublished report.

Haverschmidt, F. (1955) List of the birds of Surinam. Utrecht: Publications of the Foundation for Scientific Research in Surinam and the Netherlands Antilles, 13.

Haverschmidt, F. (1968) Birds of Suriname. Edinburgh and London: Oliver and Boyd.

Lawrence, G. N. (1880) Descriptions of two new species of parrots and a new pigeon from South America. Ibis 4(4): 237-239.

Low, R. (1972) The parrots of South America. London: John Gifford.

McLoughlin, E. P. (1970) Field notes on the breeding and diet of some South American parrots. Foreign Birds 36: 169-171, 210-213.

Meyer de Schauensee, R. (1970) A guide to the birds of South America. Narberth, Pa.: Livingston Press. (Reprinted by International Council for Bird Preservation, with new addenda 1982.)

Meyer de Schauensee, R. and Phelps, W. H. (1978) A guide to the birds of Venezuela. Princeton, N.J.: Princeton University Press.

Mittermeier, R. A. and van Roosmalen, M. G. M. (1982) Conservation of primates in Surinam. Internatn. Zoo Yearbook 22: 59-68.

Mittermeier, R. A., Malone, S. A. J., Plotkin, M. J., Baal, F., Mohadin, K., Macknight, J., Werkhoven, M. and Werner, T. B. (1990) Conservation action plan for Suriname. Washington, D.C. and elsewhere: Conservation International and others.

Niles, J. J. (1981) The status of psittacine birds in Guyana. Pp.431-438 in R. F. Pasquier, ed. Conservation of New World parrots. Washington, D.C.: Smithsonian Institution Press for the International Council for Bird Preservation (Techn. Publ. 1).

Paynter, R. A. (1982) Ornithological gazetteer of Venezuela. Cambridge, Mass.: Museum of Comparative Zoology.

Peters, J. L. (1937) Check-list of birds of the world. 3. Cambridge, Mass.: Harvard University Press.

Ridgely, R. S. (1981) The current distribution and status of mainland Neotropical parrots.

Pp. $233-384$ in R. F. Pasquier, ed. Conservation of New World parrots. Washington, D.C.: 
Smithsonian Institution Press for the International Council for Bird Preservation (Techn. Publ. 1).

Ridgely, R. S. (1982) The distribution, status, and conservation of neotropical mainland parrots. Doctoral thesis, Yale University.

Robiller, F. (1990) Papageien, 3: Mittel- under Südamerika. Berlin and Stuttgart: Deutscher Landwirtschaftsverlag and Verlag Eugen Ulmer.

Salvin, O. (1886) A list of the birds obtained by Henry Whitely in British Guiana. Ibis (5)4: $57^{-78 .}$

Schomburgk, R. (1847-1848) Reisen in Britisch-Guiana in den Jahren 1840-1844. Leipzig: J. J. Weber.

Schouten, K. (1988) Trade in parrots from Guyana. Traffic Bull. 10:14-16.

Schulz, J. P., Mees, G. F. and Kluyver, H. N. (1975) De Vogels van de Brownsberg. Paramaribo: STINASU (Natuurgids ser. B, no.3).

Snyder, D. E. (1966) The birds of Guyana. Salem: Peabody Museum.

Stephens, L. and Traylor, M. A. (1985) Ornithological gazetteer of the Guianas. Cambridge, Mass.: Museum of Comparative Zoology.

Sullivan, F. (1990) Proactive conservation in Guyana. WWF Reports August/September: $10-12$.

Tavistock, Marquess of (1929) Parrots and parrot-like birds in aviculture. London: F. V. White and Co.

Thiollay, J.-M. (1988) Les oiseaux menacés de Guyane. Pp.61-80 in J.-C. Thibault and I. Guyot, eds. Livre rouge des oiseaux menacés des régions françaises d'Outre-Mer. Saint-Cloud: Conseil International pour la Protection des Oiseaux ([ICBP] Monogr. 5).

Thiollay, J.-M. (1989) Area requirements for the conservation of rain forest raptors and game birds in French Guiana. Conserv. Biol. 3: 128-137.

D. C. WEGE and N. J. COLLAR

International Council for Bird Preservation, 32 Cambridge Road, Girton, Cambridge $\mathrm{CB}_{3}$ oPJ, U.K. 